ENTREPRENEURSHIP AND SUSTAINABILITY ISSUES

ISSN 2345-0282 (online) http://jssidoi.org/jesi/

2021 Volume 8 Number 4 (June)

http://doi.org/10.9770/jesi.2021.8.4(31)

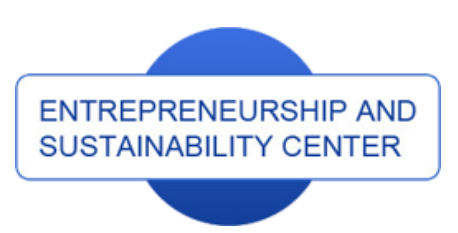

Publisher

$\underline{\text { http://jssidoi.org/esc/home }}$
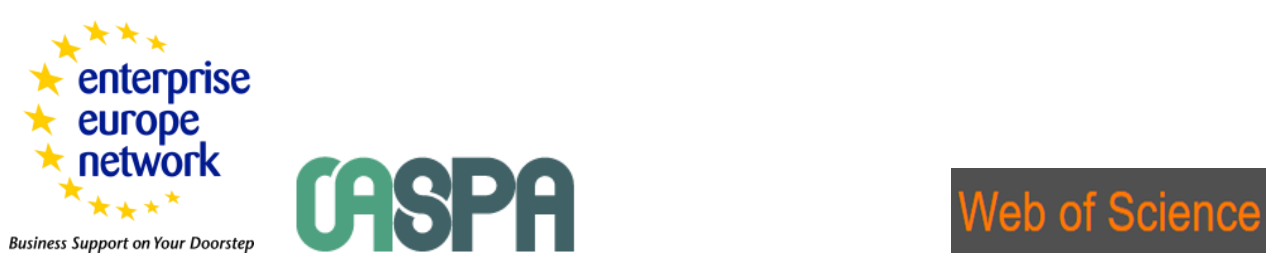

\title{
2 Clarivate \\ SELECTED DETERMINANTS OF DIGITAL TRANSFORMATION AND THEIR INFLUENCE ON THE NUMBER OF WOMEN IN THE ICT SECTOR*
}

\author{
Hana Krchová ${ }^{1}$, Katarína Švejnová Höesová ${ }^{2}$ \\ ${ }^{1}$ Department of Management and Marketing, Faculty of Economy and Business, Pan-European University, Bratislava, \\ Slovakia \\ ${ }^{2}$ School of Economics and Management in Public Administration in Bratislava, Bratislava, Slovakia
}

E-mail: ${ }^{1}$ hana.krchova@gmail.com, ${ }^{2}$ katarina.svejnova@vsemvs.sk

Received 19 November 2020; accepted 20 April 2021; published 30 June 2021

\begin{abstract}
Digital transformation offers a great opportunity for the growth of economies and societies across countries around the world. This digital transformation is leading to very rapid growth in the information and communication technology (ICT) sector. ICT currently faces two main challenges. The first problem is the lack of ICT professionals and the second significant problem is the under-representation of women among them. Our article deals with the issue of the influence of selected factors on the increase of women employed in ICT. In our survey, we focused on the influence of the following factors: The amount of GDP resulting from the ICT sector, the average annual wage, the gender gap, the number of employed women, and the number of women who work in ICT and are educated in ICT. We tested these variables on data from the V4 countries (Czech Republic, Hungary, Poland, Slovakia) for the period 2008-2018. Our aim was to find out whether the mentioned Factors are statistically significant and what is their influence on the number of employed women in the ICT sector so that it is possible to positively influence their amount as much as possible.
\end{abstract}

Keywords: digital transformation; employment of women; gender gap; ICT sector

Reference to this paper should be made as follows: Krchová, H., Švejnová Höesová, K. 2021. Selected determinants of digital transformation and their influence on the number of women in the ICT sector. Entrepreneurship and Sustainability Issues, 8(4), 524-535. http://doi.org/10.9770/jesi.2021.8.4(31)

JEL Classifications: D83, O22, M15, H430

\footnotetext{
* This research was supported by two scientific projects: Scientific Paper was elaborated and financed within the framework of the project VEGA 1/0813/19 Managing the development of innovative and start-up forms of businesses in international environment and verification of INMARK concept and GA IGP 5/2020-M Bezpečnostné riziká a krízové javy v podnikatel'skom prostredi SR (funder: VSEMvs IGA VSEMvs, i.e. School of Economics and Management in Public Administration)
} 


\section{ENTREPRENEURSHIP AND SUSTAINABILITY ISSUES}

ISSN 2345-0282 (online) http://jssidoi.org/jesi/

2021 Volume 8 Number 4 (June)

http://doi.org/10.9770/jesi.2021.8.4(31)

\section{Introduction}

Current megatrends, such as globalization and digitization, require societies to cope with the so-called "Fourth Industrial Revolution" as the digital and physical worlds come together (Schallmo et al., 2017; Butschan et al., 2019). The Fourth Industrial Revolution is expected to have similar disruptive changes comparable to the introduction of mass production (the Second Industrial Revolution) and the industrial use of information and communication technologies (the Third Industrial Revolution) (Heinze et al., 2017). As a result, companies strive to achieve efficient digital transformation processes to maximize the potential benefits of associated technologies (Laudien and Daxböck, 2016).

Over the decades, digital technologies have changed the way we communicate with others, do business, produce goods and services. They have changed the way we live, work, and spend our free time. This, often rapid, development can have many promises for the future. On the other hand, it is also necessary to think about the other side. In terms of positive challenges, this undoubtedly includes opportunities associated with the possibility of creating wealth, growing technological progress, and improving the quality of life. At the same time, they also present challenges related to possible future threats. We can see them mainly in the lack of current skills, consumer protection, or excessive industrial reorganization. (European Commission, 2015)

It is important to realize that the acceleration of technological innovation has already radically changed the use and behavior of individuals, organizations, and entire market structures. Consumers have really changed the way they choose, buy, and consume the products and services they offer. Digital technologies, such as mobile technologies, collaborative technologies, and the Internet of Things, enable companies to increase the performance of companies. This transformation driven by digital technologies is becoming crucial for companies. (Henriette et al., 2016)

\section{Literature Review}

Nowadays, the ICT the sector shows its important part to all European countries, not just because of its strategic role, its potential for employment growth in the sector itself, but also for the opportunities that the dynamic and energy ICT industry brings to business sectors, the public sector, and consumers.

Indeed, information and communication technologies are today generally considered to be essential components of economic and social development in the so-called "knowledge society" and attract the attention of governments, businesses, citizens, and civil society organizations. They represent multi-functional tools that provide great opportunities for information and communication and have applicability in the whole field of economic, social, political, and cultural life. Globalization and the dissemination of information have transformed our lives in different and profound ways.

The European Commission annually monitors the progress and level of development of digital competitiveness in individual member states using the Digital Economy and Society Index (DESI), which uses a combination of 44 indicators in five main dimensions of measurement: 1. Internet connectivity, 2. digital skills, services, 4. integration of digital technologies, and 5. digital public services. The index makes it possible to assess the overall level of digitization of society in each Member State. Furthermore, due to the division of the five dimensions into specific sub-dimensions and indicators, it identifies problematic areas to which the state should pay more attention. Finally, the index is used to compare the EU Member States. 
ENTREPRENEURSHIP AND SUSTAINABILITY ISSUES

ISSN 2345-0282 (online) http://jssidoi.org/jesi/

2021 Volume 8 Number 4 (June)

http://doi.org/10.9770/jesi.2021.8.4(31)

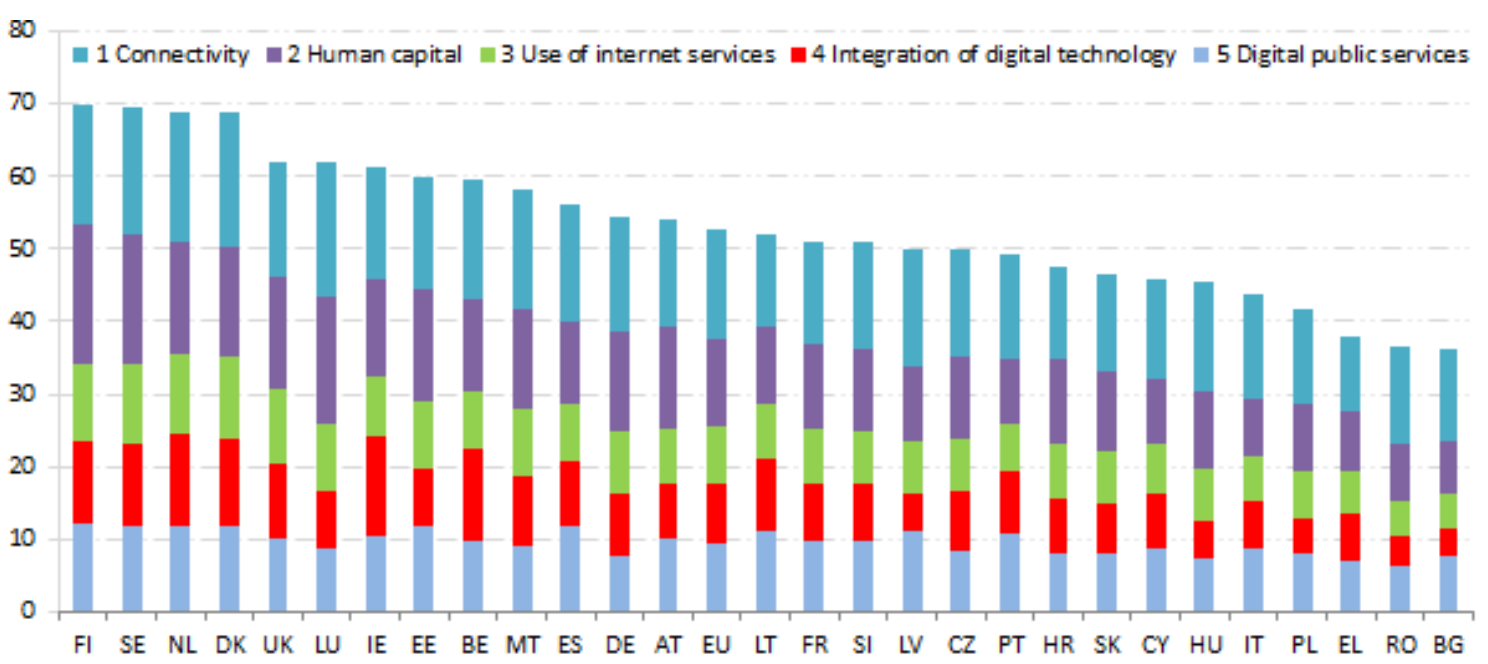

Figure 1: Digital Economy and Society Index (DESI) 2019

Source: European Commission

In this paper, we focused primarily on the V4 countries - i.e. Slovakia, the Czech Republic, Hungary, and Poland. Looking at the overall results of DESI, it is clear that the situation in our selected countries is comparable, with the Czech Republic ranking best in 18th place, followed by Slovakia in 21st place, Hungary in 23rd place and the last of our selected countries in Poland in 25th place. from 28 EU Member States.

Information and communication technologies include computers, telecommunications technologies (telephones, mobile phones, radio, radio and television broadcasting) as well as network technologies (mainly the Internet). These old and new forms of technology often converge in the forms of communication practiced in many communities. They are also tools that provide opportunities for access to information, communication, and selfexpression. Internet searches, blogs, online multimedia resources, social media, as well as services such as egovernment, e-health, e-banking, e-learning, e-commerce, electronic voting, all this create new challenges for communication, engagement, and social and economic behavior.

This rapid development of various digital technologies that can open new opportunities, new opportunities for communication, and new roles in society for women and girls. Technologies have the potential to be an effective tool for achieving equality between women and men. This sector offers highly qualified and well-paid jobs. If it is fully open to both halves of the population, it can help close the persistent gender pay gap. After all, in the Czech Republic the gender pay gap is almost 22 percent, which is the second-worst result in the European comparison.

ICT sector has created new opportunities for education and the labor market and presented new solutions for more flexible and diverse use of time and space at work. In many aspects, ICT work, in general, offers favorable working conditions, in terms of quality of work and timing that promote work-life balance. Compared to other occupations, several differences between men and women in terms of working arrangements in ICT jobs have narrowed. For example, compared to women in the health professions and other occupations, women in ICT jobs have a better physical and social environment and a better quality of working time. Atypical hours, such as working in the evening, at night and on weekends, are less common in ICT than in other jobs. Women and men in the field of ICT have more autonomy in deciding on working hours, and most of them feel that their working hours complement their family or social commitments. (EIGE, 2018) 


\section{ENTREPRENEURSHIP AND SUSTAINABILITY ISSUES}

ISSN 2345-0282 (online) http://jssidoi.org/jesi/

2021 Volume 8 Number 4 (June)

http://doi.org/10.9770/jesi.2021.8.4(31)

Despite increasing participation, women are still under-represented in the labor market (on average, $62.3 \%$ of the OECD workforce averaged $62 \%$ in 2012). They also employ more than 50\% of central government jobs, but only $29 \%$ of management positions. In addition, there is a significant reduction in the participation of women in the ICT sector in almost all Central European countries (up to 10 percentage points), but also in Austria, Denmark, France, the United Kingdom and Ireland ( 3 to 5 percentage points). The only European countries where the proportion of women in STEM has actually increased slightly are Estonia, Belgium, and Malta. More generally, however, women are under-represented in their STEM careers and this trend is spreading in many European countries. (OECD, 2014)

Today, the digital transformation provides new opportunities for women's empowerment in the economy and can contribute to greater equality between women and men. The Internet, digital platforms, and digital financial services offer "leap" opportunities for all and can help bridge the gap by enabling women to earn extra income, increase their employment opportunities and gain access to knowledge and general information. We must seize this opportunity to promote greater equality between women and men in the labor market, to promote economic growth, and to build a more inclusive digital world. (OECD, 2018)

The issue of digitization also concerns the reconciliation of work and family life. Digitization enabled by temporal and spatial flexibility of work is used mainly by women due to their increased need for malt in workplaces and family life. At the same time, however, the ideas of a capable and promising employee, who is a person with a high work commitment and a high degree of flexibility for the benefit of employers, do not change. Such a profile often corresponds to male employees. The digitization of the labor market can thus, as a result, contribute to the worse position of women in the labor market. (Úřad vlády ČR, 2018)

\subsection{Women in ICT}

Digital transformation offers a huge opportunity for the growth of economies and societies across countries around the world. However, the benefits of digital transformation are currently not evenly balanced between social groups and the sexes, and access, use, and ownership of digital tools are not gender neutral. The term "digital gender divide" is often used to refer to these types of gender differences in the resources and capabilities of accessing and effectively using ICT within and between countries, regions, sectors, and socio-economic groups (see UN Women, 2005).

Equality between women and men is not just a fundamental human right. It is also a cornerstone of a thriving modern economy that ensures sustainable and inclusive growth. Digital Transformation - offers new opportunities around the world and promises to increase productivity growth and improve the well-being of all citizens. However, in many developed economies, there is still a significant gender gap in the access, use, and ownership of digital technologies, which limits the equitable use of the benefits of digital transformation. Furthermore, transformation fundamentally changes the content and nature of jobs and the skills needed to perform them. This uncertainty about future employment will weigh on the potential impact of digitalization on the labor market for women: new and more flexible jobs can foster greater labor market participation and better jobs, but new challenges arise as automation and ICT spread across sectors and occupations and potentially disrupt existing labor policies and standards. New knowledge is needed to provide evidence that will enable governments to accurately diagnose problems and take steps to empower all individuals, but especially women, in our increasingly digital world. (OECD, 2018)

In the following picture we can see the percentage of women with ICT education in relation to the percentage of women working in the ICT sector. The red trend line shows a situation where the percentage of women employed in the ICT sector would be equal to the percentage of women with ICT education. In other words, countries, 
where all women with an ICT education would work in the ICT sector, would be on the red line. If we focus on the V4 countries, we can see that in Slovakia, the Czech Republic, and Hungary, women with an ICT education mostly work outside the ICT sector (most notably in Slovakia). In contrast, in Poland, most women working in the ICT sector do not have an ICT education.

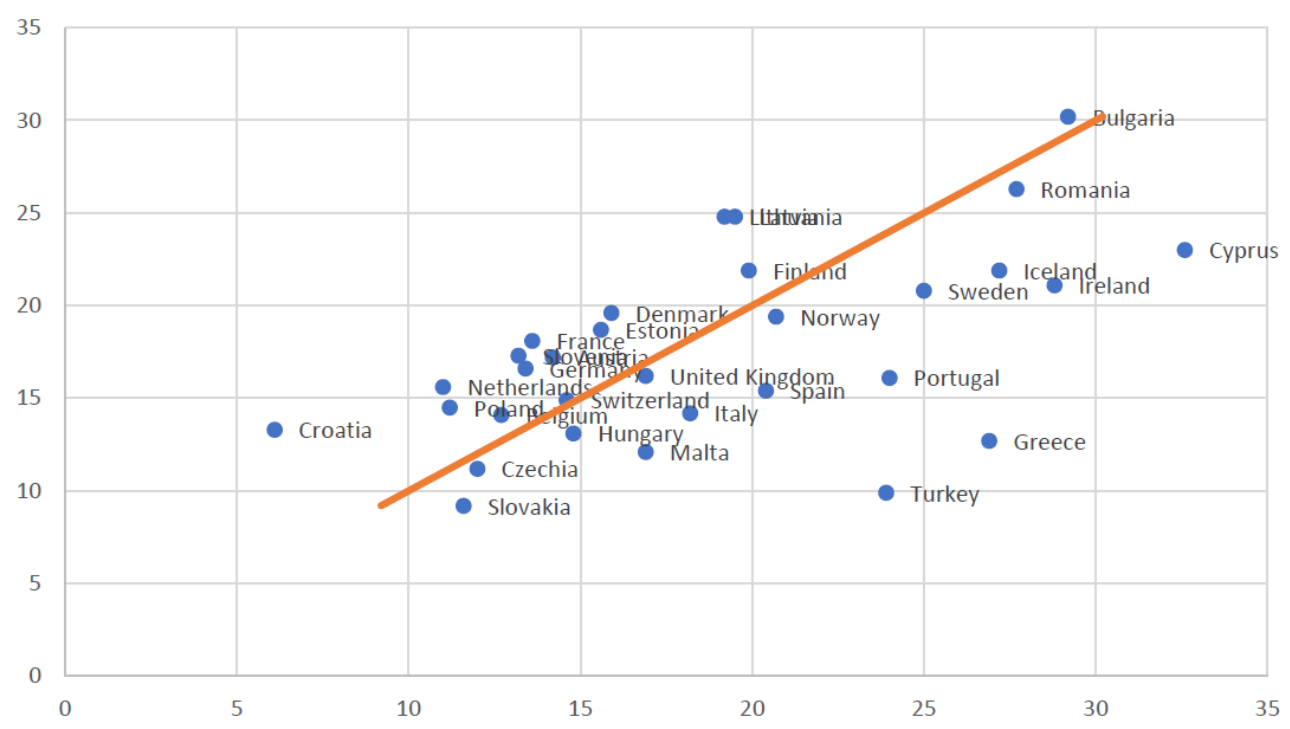

Figure 2: Women as percentage of all ICT specialists and as percentage of all employed in ICT sector Source: Simonsen et al., 2019

If we focus on the number of women ICT specialists in the V4 countries we are monitoring, we can see the results as presented by Eurostat in the figure 2. When the lowest number of women in 2019 from the V4 states was $8.9 \%$ in Hungary and $14.8 \%$ the most in Poland. Unfortunately, even this number does not reach the EU average of $17.2 \%$, let alone the values of the Nordic countries.

For comparison, we can also present the development of these parameters over time as shown in the following figure 3 .

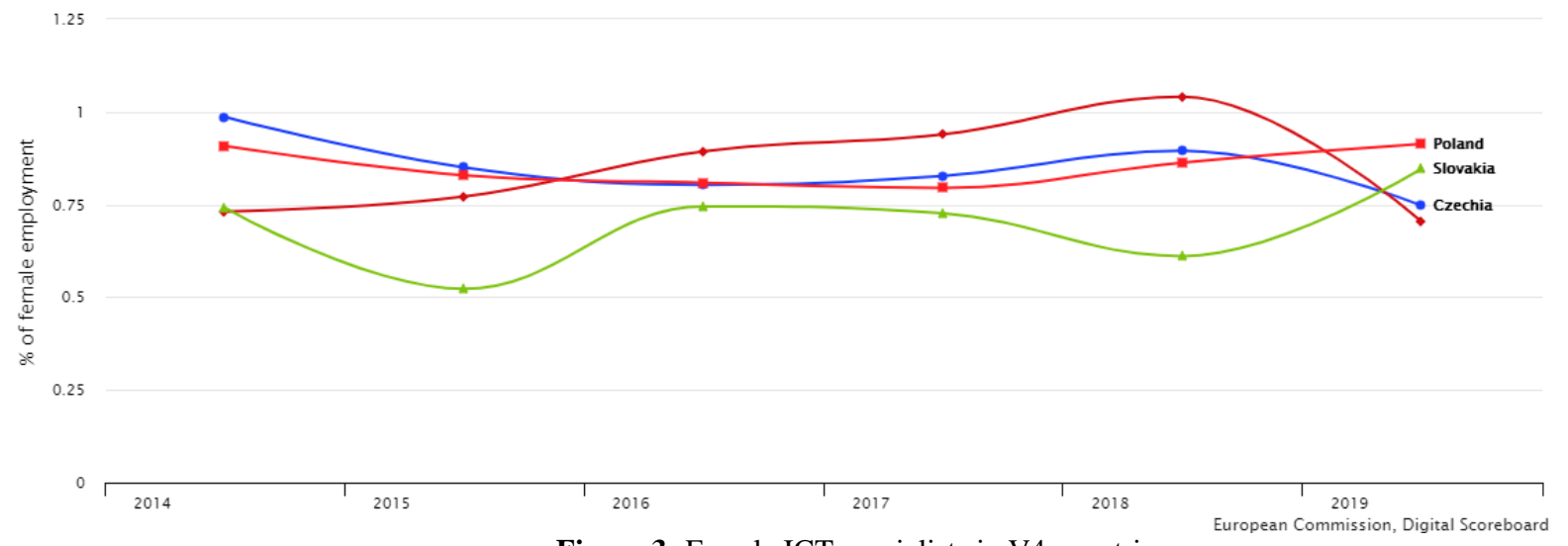

Figure 3: Female ICT specialists in V4 countries

Source: Eurostat 


\section{ENTREPRENEURSHIP AND SUSTAINABILITY ISSUES}

ISSN 2345-0282 (online) http://jssidoi.org/jesi/

2021 Volume 8 Number 4 (June)

http://doi.org/10.9770/jesi.2021.8.4(31)

\subsection{Gender gap}

The gender pay gap is a well-known phenomenon. Numerous studies and organizations have confirmed that women are paid less than men (UN Women, 2015). This is partly due to segregation and gender stereotypes; women are associated with traditionally "female" occupations and these are associated with worse working conditions and lower wages (Prokos et al., 2009; Stockdale et al., 2013). ICT and the digital industry are specific barriers for women. Technology-related jobs are traditionally filled by men.

This is an area where the most pronounced impact of stereotypes is evident, which represent barriers to women's access and create barriers to their development (Sharp et al., 2012; Hari, 2016). Women in these sectors are perceived primarily as women, not as ICT workers or engineers (Faulkner, 2009; Hatmaker, 2013); this affects the types of positions they hold and their promotion within organizations through horizontal and vertical professional segregation (Valenduc, 2011). As a result, they are more likely to receive lower salaries than men (Iglesias Fernández et al., 2010; Belgorodskiy et al., 2012; Shen, 2016; European Commission, 2018a).

Various international organizations and the private sector are aware of the traditional over-representation of men in the ICT sector and have emphasized the desirability of attracting more women to the sector, as women have "untapped potential for the sector" (Valenduc, 2011). This perception has deepened as a result of the Fourth Industrial Revolution, the so-called Industry 4.0 phenomenon, which renewed interest in robotics, automation, and intelligence of products and systems (Schneider, 2018) and focused on the major role of ICT in the future, (International Labor Office, 2018). Indeed, recent technological developments have increased the pressure to address the low participation of women in ICT sectors and professions. In the European Union, in 2015, tertiary ICT graduates accounted for only 3.6 percent of all graduates, of which only 19 percent were women. This gap is reflected in the professional sphere: in 2015, only $16.1 \%$ of all ICT workers were women, which is less than 22.2\% registered in 2005 (European Commission, 2018a). This gap is serious throughout the EU, but there are differences between countries (European Commission, 2018a) with different economic and social contexts.

As reported by Anker (1998), data suggest that the existence of segregation in the ICT sector, such as discriminatory social norms or indirect discrimination (eg work attributes, employment conditions), institutional or organizational factors (Belgorodskiy et al., 2012), and stereotypical barriers could lead to differences in working conditions in different countries. The study of different national and cultural contexts is therefore essential to address the gender imbalances that characterize ICT industries and professions (European Commission, 2018a).

However, the gender pay gap remains a major challenge and remains one of the highest in the EU. The gender pay gap is also reflected, for example, in differences in the average old-age pensions of women and men and in the persistently higher risk of poverty for older women. Despite some partial activities of the public administration aimed at promoting equal pay, the gender pay gap is declining only very slowly and by 2020 it will certainly not be possible to reach the goal set in the Government strategy (to reach the average gender pay gap in the EU, which is currently 16\%). However, the gender pay gap remains a major challenge and remains one of the highest in the EU. The gender pay gap is also reflected, for example, in differences in the average old-age pensions of women and men and the persistently higher at-risk-of-poverty rate for older women. Despite some partial activities of the public administration aimed at promoting equal pay, the gender pay gap is declining only very slowly and by 2020 it will certainly not be possible to achieve the goal set in the Government strategy (to reach the average gender pay gap in the EU, which currently stands at 15.9\%).(Úřad vlády ČR, 2018).

The Gender Equality Index, a tool for measuring progress on gender equality in the EU and developed by EIGE. It raises the profile of areas for improvement and ultimately supports policymakers in proposing more effective 


\section{ENTREPRENEURSHIP AND SUSTAINABILITY ISSUES}

ISSN 2345-0282 (online) http://jssidoi.org/jesi/

2021 Volume 8 Number 4 (June)

http://doi.org/10.9770/jesi.2021.8.4(31)

gender equality measures. The EIGE Gender Equality Index shows that progress on gender equality is still evolving at a snail's pace, but we are moving in the right direction. While the score of the Gender Equality Index in the EU rose from 66.2 points (out of 100) in 2015 to 67.4 in 2017, the EU still has much room for improvement. Since 2005, the EU score has increased by only 5.4 points. Unfortunately, in our V4 countries, the situation is even worse when the lowest rating in this score is Hungary 51.9 points (out of 100 points), followed by Slovakia 54.1 points (out of 100 points), followed by Poland 55.2 points (out of 100 points) and the best of us The Czech Republic finished with 55.7 points (out of 100 points), which are, however, still significantly lower than the EU average. (EIGE, 2019)

\section{Date, Methodology and Research Results}

As part of our research, we focused primarily on answering the question: Is it possible to use selected factors to change the number of women working in the ICT sector? Based on a literature search, we then looked for factors that could affect how many women work in the ICT sector. This issue is important because we assume that the growth of this ratio can lead to positive results in the development of innovative companies. The key factors which are subsequently subjected to regression analysis, we consider both the factor that determines our level of development of the ICT sector in the national economy. Subsequently, we chose a factor that indicates the number of employed women who completed ICT Education. For equally important to also consider how high the average wage in the country or how big they are in the country gender differences. Research limitations can be registered with in the quality of the data used obtained from Eurostat and OECD databases. This part further examines the selected determinants, using the method of regression analysis of panel data for the period 2008-2018 on data for the Czech Republic, Slovakia, Hungary and Poland. The data source that we used for the analysis was obtained from Eurostat and OECD databases. The reason for limiting the time series is the lack of current data for the following years.

We focused our research on determining the influence of selected factors on the number of women who work in ICT. On average, approximately $15.8 \%$ of women in the V4 countries are employed in ICT. Across the EU, the figure is $17.2 \%$. The World Bank formally defines the participation rate of women in the labor force as the share of women in the labor force, which is within the age group 15-64. As an explanatory variable for determining this effect on the number of women in ICT, we use as the first number of employed women who have studied ICT. Other explanatory variables are used selected relevant ICT indicators. These explanatory variables are the indicators Percentage share of the ICT sector in a country's GDP, the ratio of women employed in each country, the average annual wage in each country, and the Gender gap. All data used are drawn from the Eurostat and OECD databases. Summary statistics on the main variables (including mean, standard deviation, and minimum and maximum values) are given in Table 1.

The resulting variables, ICT development indicators, and control variables are marked as "Y", "T" and "X". As usual, $b$ is a constant, and a and $u$ are estimates, while the error term is shown as E: The country and time identifiers are " $i$ " and "t". Use of panel data, where we use data for individual V4 countries and at the same time data from the time period 2009-2018:

$y_{i t}=\alpha_{i}+\beta_{1} x_{i t 1}+\beta_{2} x_{i t 2}+\beta_{3} x_{i t 3}+\beta_{4} x_{i t 4}+\mathrm{u}_{i t}$,

where y: fe_ict (is a dependent variable) - the number of women working in ict X1 ict_hdp - share of the ICT sector in the GDP of the given country

X2 ict_educated_e_female - number of employed women who graduated from ICT

$\mathrm{X} 3$ wage - the average annual wage in a given country

$\mathrm{X} 4 \mathrm{gp}$ - gender gap in the given country

$\mathrm{u}$ - is a random component 
Table 1: Statistical description of the individual variables

\begin{tabular}{|c|c|c|c|c|}
\hline Variable & Mean & Std. Dev & Min & Max \\
\hline fe_itc & 158,275 & 8,65 & 8.5 & 39 \\
\hline zam_fe & 3029,25 & $2,380,101$ & 1012,6 & 7199,1 \\
\hline gp & 11.94286 & 3,779 & 3,773 & 16,4552 \\
\hline wage & 23320,75 & $1,916,359$ & 20150 & 29106 \\
\hline ict_ed-female & 13,1525 & 14,315 & 1.1 & 48,2 \\
\hline ict_hdp & 4,422275 & 0.960267 & 3.01 & 6.11 \\
\hline \multicolumn{5}{|c|}{ Source: the authors } \\
\hline
\end{tabular}

The aim of the regression analysis using panel data is to determine the degree of influence of individual determinants on the number of women in ICT. Based on the results of previous research on this issue, we have established the following hypotheses:

- Reducing the gender gap leads to an increase in the number of women in the ICT sector. (The null hypothesis $\mathrm{H} 0=$ Gender Gap has no effect on increasing the number of women in the ICT sector.)

- Increasing the employment of women leads to an increase in the number of women in the ICT sector. (Zero hypothesis $\mathrm{H} 0=$ Higher number of working women does not affect the increase in the number of women in the ICT sector.)

- Increasing the average wage leads to an increase in the number of women in the ICT sector. (Null hypothesis $\mathrm{H} 0=$ Increasing the average wage does not affect the increase in the number of women in the ICT sector.)

- Increasing the number of women with ICT education will have an impact on increasing the number of women in the ICT sector. (Null hypothesis $\mathrm{HO}=$ Increasing the number of women with ICT education does not affect the increase in the number of women in the ICT sector.)

- Increasing GDP in the ICT sector leads to an increase in the number of women in the ICT sector. (Null hypothesis $\mathrm{HO}=$ Increasing GDP in the ICT sector does not affect the increase in the number of women in the ICT sector.)

Table2: Results of regression analysis of panel data

\begin{tabular}{|c|c|c|c|c|}
\hline fe_itc & Coef. & Std. Err. & t-Statistic & P>|t| \\
\hline zam_fe & 0,0724273 & 0,005 & 14,25 & $0,000^{* * *}$ \\
\hline gp & 3.840218 & 140,065 & 2,74 & $0,006^{* *}$ \\
\hline wage & 0,0048912 & 0,001832 & 2,67 & $0,008^{* *}$ \\
\hline ict_ed-female & -2.827609 & 0,8333 & $-3,39$ & $0,001 * * *$ \\
\hline ict_hdp & 33.28199 & $6,125,953$ & 5,43 & $0,000^{* * *}$ \\
\hline \multicolumn{5}{|c}{ Source the authors } \\
\hline
\end{tabular}

We decided to use model with random effects, that came from the results of the Hausmann and Breuch-Pagan test. The robustness of the results was subsequently tested by several tests. A positive result was obtained in all tests.

$y_{i t}=-316,91+33.28 x_{i t 1}-2.82 x_{i t 2}+0.005 x_{i t 3}+3.84 x_{i t 4}+\mathrm{u}_{i t}$, 


\section{ENTREPRENEURSHIP AND SUSTAINABILITY ISSUES}

ISSN 2345-0282 (online) http://jssidoi.org/jesi/

2021 Volume 8 Number 4 (June)

http://doi.org/10.9770/jesi.2021.8.4(31)

The results from the regression analysis of panel data are presented in Table 2. The analysis of panel data confirmed the significance of all investigated determinants (rejection of null hypotheses related to these determinants). The results of the regression analysis of the panel data lead to the rejection of all null hypotheses about any influence of determinants on the employment of women.

Reducing the gender gap leads to an increasing number of employed women in the ICT sector, which proved to be statistically significant at the $1 \%$ level of significance. In other words, the p-value is low enough to reject the null hypothesis. We can, therefore, say that the shrinking gender gap has an impact on increasing the number of women in the ICT sector. We can also reject the null hypothesis for women's employment, which has a positive impact on the number of women employed in the ICT sector. The increase in the average wage leads to an increase in the number of women in the ICT sector, which we have demonstrated at the 5\% level of statistical significance. Increasing GDP in the ICT sector does not affect the increase in the number of women in the ICT sector as null hypothesis should be rejected as well as the hypothesis that the increasing the number of women with ICT education does not affect the increase in the number of women in the ICT sector. Increasing GDP in the ICT sector has affected the increase in the number of women in the ICT sector, it should be rejected the null hypothesis and the hypothesis that an increasing number of women to education, ICT has no impact on increasing the number of women in the ICT sector.

In other words, all our hypotheses have been confirmed and the results clearly show that the growth of GDP in the ICT sector has the greatest impact on an increasing number of employed women in the ICT sector. Appropriate also to consider finding that substantially negative value of women educated in ICT corresponds to our previous findings presented in the article, when only the Polish women working in ICT also worked in ICT and in other V4 countries we reviewed this trend was reversed. Of the other results, we also consider the fact that if the Gender gap decreases, the number of women employed in ICT will start to grow. This fact is also supported by data from the Eurostat database, which shows the fact that the gender pay gap is even greater in the ICT sector than in other businesses.

\section{Conclusion}

Gender equality in education and the labor market is a prerequisite for a sustainable society and more efficient economies. At a time of deep digitization and rapid growth of the ICT sector, the EU faces two main challenges: the lack of ICT professionals and the significant under-representation of women among them. The demand for ICT professionals is particularly high and there is a shortage of more than 500,000 ICT experts in the EU forecast by 2020 . While women have on average a higher level of education in the EU than men, in the EU only a fraction of the potential of women is used in the STEM professions and especially in ICT (EIGE, 2017c). Of the 8 million ICT professionals, only 17\% are women. From 2012 to 2016, there was a small improvement in women's participation in ICT jobs in the EU. EIGE estimates that attracting more women to STEM jobs would strengthen the labor-congested market (creation of up to 1.2 million new jobs by 2050), with a profit of around $€ 820$ billion by 2050 (EIGE, 2017a). It would also strengthen the growth and competitiveness of European Union countries.

The unequal sharing of caring roles between women and men is another serious obstacle to work-life balance. Although gaps in the care of women in ICT are smaller than in other professions, inequalities persist. It is expressed in the different length and structure of working time between women and men in ICT jobs and in different ways to keep up with work pressure and responsibilities at home. On average, men specialize in ICT specialists longer than their colleagues. Although part-time work is relatively less common among ICT professionals, childcare, and other family or personal reasons are among the most common reasons why women work part-time in ICT. Longer working hours among men lead to lower acceptance of family responsibilities or, conversely, more active contribution of men to family and caring responsibilities is hampered by longer working 


\section{ENTREPRENEURSHIP AND SUSTAINABILITY ISSUES}

ISSN 2345-0282 (online) http://jssidoi.org/jesi/

2021 Volume 8 Number 4 (June)

http://doi.org/10.9770/jesi.2021.8.4(31)

hours and greater commitment to working. In addition, more women than men in ICT jobs feel that their work prevents them from devoting time or most of their time to their families. It reflects gender stereotypes and expectations regarding parenting by different standards for good mothers and good fathers. (EIGE, 2018)

However, the current situation with Covid-19 has shown us new opportunities to work from home and there is a strong assumption that although the economy and related problems will certainly slow down now, it could also be reflected in the possibility of better employment for women by introducing more home. Our research has clearly demonstrated the importance of the individual factors we used in the research. If we want to increase the participation of women in the ICT sector, it is necessary to pay attention to each parameter separately.

\section{Acknowledgements}

The paper is the output of anional scientific project Scientific Paper was elaborated and financed within the framework of the project VEGA 1/0813/19 Managing the development of innovative and start-up forms of businesses in international environment and verification of INMARK concept and GA IGP 5/2020-M "Bezpečnostné riziká a krízové javy v podnikatel'skom prostredi SR” (Funder: VSEMvs IGA VSEMvs, i.e. School of Economics and Management in Public Administration)

\section{References}

Anker, R. (1998). Gender and Jobs. Sex Segregation and Occupations in the World (Geneva: International Labour Office).

International Labour Office (2018), The Impact of Technology on the Quality and Quantity of job, Issue brief number 6, prepared for the 2nd Meeting of the Global Commission on the Future of Work, 15-17 February 2018, https://www.ilo.org/wcmsp 5/group s/publi c/dgrep orts/_cabin et/docum ents/publi catio n/wcms_618168.pdf

Belgorodskiy, A., B. Crump, M. Griffiths, K. Logan, R. Peter and H. Richardson (2012). The Gender pay gap in the ICT Labour Market: Comparative Experiences From the UK and New Zealand. New Technology, Work and Employment, 27, 2, $106-119$.

Butschan, J.S., Heidenreich, Weber, B. and Krämer, T. (2019). Tackling hurdles to digital transformation — The role of competencies for successful industrial internet of things (IIoT) implementation. International Journal of Innovation Management, 23(04), 1950036. https://doi.org/10.1142/S1363919619500361

European Commission, 2015, Monitoring the Digital Economy \& Society $2016-2021$. https://ec.europa.eu/eurostat/documents/341889/725524/Monitoring+the+Digital+Economy+\%26+Society+2016-2021/7df02d85-698a$\underline{4 a 87-a 6 b 1-7994 d f 7 f b e b 7}$

European Commission, 2018, DESI 2019 Methodological note. https://ec.europa.eu/newsroom/dae/document.cfm?doc_id=59913

European Commission (2018a). Women in the Digital Age (Luxembourg: European Commission), https://ec.europa.eu/digitalsinglemarket/en/news/increase-gender-gap-digital-sectorstudy-women-digital-age

European Institute for Gender Equality (EIGE) (2017a). Economic benefits of gender equality in the European Union - Literature review: existing evidence and methodological approaches, Publications Office of the European Union, Luxembourg, available at: http://eige.europa.eu/sites/default/files/documents/ti_pubpdf_mh0116176enn_pdfweb_20170516164243.pdf

European Institute for Gender Equality (EIGE) (2017c). Study and work in the EU: set apart by gender — Review of theimplementation of the Beijing Platform for Action in the EU Member States. https://eige.europa.eu/news/study-and-work-eu-set-apart-gender

European Institute for Gender Equality (EIGE) (2018). Women and men in ICT: a chance for better work-life balance Research note Publications Office of the European Union, Luxembourg, available at: https://op.europa.eu/en/publicationdetail//publication/dc40b38ec6b8-11e8-9424-01aa75ed71a1/language-en/format-PDF/source-77217025 


\section{ENTREPRENEURSHIP AND SUSTAINABILITY ISSUES}

ISSN 2345-0282 (online) http://jssidoi.org/jesi/

2021 Volume 8 Number 4 (June)

http://doi.org/10.9770/jesi.2021.8.4(31)

Faulkner, W. (2009). Doing Gender in Engineering Workplace Cultures. II. Gender in/Authenticity and the in/Visibility Paradox. Engineering Studies 1(3), 169-189. https://doi.org/10.1080/19378620903225059

Hari, A. (2016). Who Gets to 'Work Hard, Play Hard'? Gendering the Work-Life Balance Rhetoric in Canadian Tech Companies. Gender, Work \& Organization 24(2), 99-114. https://doi.org/10.1111/gwao.12146

Hatmaker, D.M. (2013). Engineering Identity: Gender and Professional Identity Negotiation Among Women Engineers. Gender, Work \& Organization 20(4), 382-396. https://doi.org/10.1111/j.1468-0432.2012.00589.x

Heinze, R, C Manzei and L Schleuper (Eds.) (2017). Industrie 4.0 im internationalen Kontext: Kernkonzepte, Ergebnisse, Trends. Berlin: Beuth Verlag. 261p. ISBN: 978-3-410-26049-3

Henriette, E., Feki, M., \& Boughzala, I. (2016, September). Digital Transformation Challenges. In MCIS (p. 33) https://aisel.aisnet.org/mcis2016/33

Iglesias-Fernández, C., Llorente-Heras, R. and Dueńas, D. (2010). ICT Employment, Over-Education and Gender in Spain: Do Information and Communication Technologies Improve the Female Labour Situation?. New Technology, Work and Employment 25(3), 238-252. https://doi.org/10.1111/j.1468-005X.2010.00251.x

Laudien, S.M. and Daxböck, B. (2016). The influence of the industrial internet of things on business model design: A qualitative-empirical analysis. International Journal of Innovation Management, 20(8), 1640014. https://doi.org/10.1142/S1363919616400144

OECD (2014) Enhancing Women's Economic Empowerment Through Entrepreneurship and Business Leadership in OECD Countries. Paris: OECD. http://www.oecd.org/gender/Enhancing\%20Women\%20Economic\%20Empowerment_Fin_1_Oct_2014.pdf

OECD (2018) Bridging the digital gender divide. Paris: OECD http://www.oecd.org/internet/bridging-the-digital-gender-divide.pdf

Prokos, A.H., I. Padavic and S.A. Schmidt (2009). Nonstandard Work Arrangements Among Women and men Scientists and Engineers. Sex Roles 61, 653-666. https://doi.org/10.1007/s11199-009-9680-y

Schallmo, D, Willians, C.A. and Boardman, L. (2017). Digital transformation of business models - Best practice, enablers and roadmap. International Journal of Innovation Management, 21(8), 1-17. https://doi.org/10.1142/S136391961740014X

Schneider, P. (2018). Managerial Challenges of Industry 4.0: An Empirically Backed Research Agenda for a Nascent Field. Review of Managerial Science, Springer 12(3), 803-848. https://doi.org/10.1007/s11846-018-0283-2

Sharp, R.S., Franzway, J. Mills, J. and Gill, J (2012). Flawed Policy, Failed Politics? Challenging the Sexual Politics of Managing Diversity in Engineering Organizations. Gender, Work \&Organization 19(6), 555-572. https://doi.org/10.1111/j.1468-0432.2010.00545.x

Shen, H. (2016). Why Women Earn Less: Just two Factors Explain Post-PhD pay gap. Nature. http://www.nature.com/news/whywomenearn-less-just-two-factors-explain-post-phdpay-gap-1.19950\#auth-1 (viewed 10 February 2017).

Simonsen, Morten \& Corneliussen, Hilde. (2019). Can Statistics Tell Stories about Women in ICT? Tracing men and women's participation in fields of ICT throgh statistics for Norway, Nordic countries and Europe.Nordic Centre of Excellence on Women in Technology Driven Careers. Vestlandsforsking-rapport nr. 14/2019. ISBN: 978-82-428-0412-9

Stockdale, M.S. and Nadler, J.T. (2013). Paradigmatic Assumptions of Disciplinary Research on Gender Disparities: The Case of Occupational sex Segregation. Sex Roles 68(3-40, 207-215. https://doi.org/10.1007/s11199-012-0228-1

UN Women (2015), Progress of the World's Women 2015-2016: Transforming Economies, Realizing Rights (Milan: UN Women), http://progress.unwomen.org/en/2015/pdf/UNWprogressreport.pdf (viewed 10 February 2017).

Úřad vlády ČR. (2018) Zpráva za rok 2017 o rovnosti žen a mužů (Report for 2017 on equality between women and men) https://www.vlada.cz/assets/ppov/rovne-prilezitosti-zen-amuzu/dokumenty/zprava2017.pdf

Valenduc, G. (2011). Not a job for Life? Women's Progression, Conversion, and Dropout in ICT Professions. International Journal of Gender, Science and Technology 3(2), 483-500. http://genderandset.open.ac.uk/index.php/genderandset/article/viewFile/172/343 
Ing. Hana KRCHOVÁ, Ph.D. is an Assistant Professor of the Department of Management and Marketing, Faculty of Economy and Business, Pan-European University, Bratislava, Slovak Republic. Her research interests are: Projects, Project Management, Innovation Management, and Strategic Management.

ORCID ID: orcid.org/0000-0003-3550-5300

Ing. Katarína Švejnová Höesová is an Assistant of the Department of Management, School of Economics and Management in Public Administration in Bratislava, Slovak Republic and is PhD candidate at University of Economics in Prague. Her research interests are: Pension systems, Gender Gap, Social Sesurity and Workforce productivity.

ORCID ID: orcid.org/0000-0001-5730-5364

Make your research more visible, join the Twitter account of ENTREPRENEURSHIP AND SUSTAINABILITY ISSUES: @Entrepr69728810

Copyright (C) 2021 by author(s) and VsI Entrepreneurship and Sustainability Center This work is licensed under the Creative Commons Attribution International License (CC BY).

http://creativecommons.org/licenses/by/4.0/

(c) (†) Open Access 